\title{
Articles
}

Central European Review of Economics \& Finance

Vol. 21, No. 5 (2017), pp. 7-23. D0I: 10.24136/ceref.2017.019

Tadeusz Dyr ${ }^{1}$, Karolina Ziółkowska ${ }^{2}$, Agata Jaździk-0smólska ${ }^{3}$, Małgorzata Kozłowska ${ }^{4}$

\section{ECONOMIC SAFETY ASPECTS OF THE ROAD TRAFFIC IN POLAND}

Road accidents are generating economic and public high costs. They include: losses resulting from the long-lasting or temporary impossibility of creating GDP, expenses on the treatment and rehabilitation of people injured in the accidents, costs of emergency services involvment, payment of compensations and benefits, financial losses or emotional suffering of the accidents' victims and perpetrators' relatives, leading to reduce their economic activity. Statistical data presented in the point out to the high risk of road accidents. Also causes of unsatisfactory level of the road safety improvement in Poland were presented.

JEL Classification Codes: R41, I38.

Keywords: accidents, social cost, EU transport policy.

\section{Introduction}

The rapid development of the automotive industry generates - apart from benefits, associated with the mobility and the economy growth - high economic and public costs. These costs result mainly from the negative influence of the road transport to the natural environment, including those lead-

\footnotetext{
${ }^{1}$ Associate Professor, Ph.D., K. Pulaski University of Technology and Humanities in Radom, Faculty of Economic and Legal Sciences.

${ }^{2}$ Assistant Professor, Ph.D., University of Social Sciences in Lodz.

${ }^{3}$ MSc, Road and Bridge Research Institute, M.A., Ph.D. student, K. Pulaski University of Technology and Humanities in Radom, Faculty of Economic and Legal Sciences.

${ }^{4}$ M.A., Ph.D. student, K. Pulaski University of Technology and Humanities in Radom, Faculty of Economic and Legal Sciences.
} 
ing to the climate change, congestion and high-risk of road accidents. All over the world every day as a result of road events 140 thousand people are injured in road accidents. Over 3 thousand die, and about 15 thousand will never fully recover (World Health Organization, 2015). The increase in the risk of road accidents caused the need to define, unknown 30 years ago, a new category of mortality caused by so-called external factors, that include antisocial individual's behavior.

In 1990 the road traffic was on 9th place amongst illnesses' causes, complaint and injuries in the global scale. Last data from 2013 is put the road accidents on 5th place amongst causes of premature deaths and disability, and it is predicted that up to 2020 it can even be the 3rd place in this classification (Murray and Lopez, 1996).

Noticing economic and social negative effects of accidents, the European Commission undertakes numerous activities aimed at improvement in the road safety. In the White Paper from 2001 (COM 370. 2001) the European Commission acknowledged that to 2010 the number of road accident victims should be reduce by half. For the achievement of this aim implementing instruments in the scope of penalties harmonization and new technologies promotion was suggested.

In the road safety improvement program from 2010 (COM 389. 2010) a need to approach the highest road safety standards in entire Europe was assumed, which is a reduction of road fatalities by the half until 2020 . In order to reach that objective an integrated approach to the road safety including improving an educational system and training road users, improvement in enforcing traffic regulations, increasing the safety of the road infrastructure and vehicles, propagating use of modern technologies, improvement of services in emergencies, post-injuries services and protection of road users peculiarly exposed to accidents (motorcyclists, moped riders, cyclists and pedestrians) was suggested.

Considering presented premises, as the crucial objective of the article a presentation of economic and public road safety aspects an evaluation of the security level - measured by the number of accident and their effects in the European Union and in Poland were accepted. The article also draws attention to causes of the unsatisfying level of road safety improvement in Poland. 


\section{Theoretical aspects of the road safety}

Along with the demographic, economic and social development dominating standards of morbidity and mortalities are changing. A successful attempt to explain them is a theory of the epidemiological proceeding (Wróblewska, 2009). This theory for the first time was described in 1971 by Abdela R. Omrana (Omran, 1971). Analysis results of the mortality, profiles of illnesses and social-economic processes changes which were observed amongst industrialised countries since the 18th century were its base. According to this theory populations experience three consecutive phases: epidemic and hunger (when the mortality is kept on the very high level), reduction in incidence of infectious diseases (when life expectancy grows up to nearly 50 years) and phase of degenerative diseases, (during which the pace of the drop in mortality is weakening, and together with the decrease of mortality caused by infectious diseasesas there is an increase in the mortality caused by chronic diseases).

This theory has many alterations and extensions. Within its scope a new category of mortalities caused by external causes of deaths and deaths connected to antisocial behaviors, including those resulting from communications accidents was identified (Rogers and Hackenberg, 1987).

Current problem of a higher mortality in the world is assigned to occurrence of the centre stage of epidemiological proceeding, called hybrid era. At this stage countries are increasing their level of development, burdens of infectious diseases are decreasing and a life expectancy is increasing. On the other hand, the current transitional phase in the complicated way affects burden of other disease and disability. In this phase the morbidity and mortality are characterized by a great participation of degenerative and civilization diseases transformations associated with the social changes process, as well as resulting from individual behaviours, including destructive lifestyle orientated at sensual pleasures, e.g. smoking, alcohol and drug consumption, or speeding.

Essential antisocial behaviour affecting the level of road safety is drink driving. Examinations confirm that there is a correlation between the blood alcohol level, and the level of risk of an accident. In case of blood alcohol level by $0.8 \mathrm{mg} / \mathrm{ml}$ (it is permissible value in some states) the risk of an accident is 2.7 times higher than at the sober driver. The alcoholic strength of $1.5 \mathrm{mg} / \mathrm{ml}$ causes, that the risk of the accident is 22 times higher than at sober drivers (fig. 1). Alcohol has also a significant influence on accidents' effects. Risk of fatal caused by drivers, whose blood alcohol level amounts 
to $1.5 \mathrm{mg} / \mathrm{ml}$ is 200 times higher than at sober drivers (SafetyNet, 2009). In case of BAC above $0.05 \%$ the risk function of the accident has exponential character (Krüger and Vollrath, 2004). The risk increase becomes more distinct after exceeding the level of $0.1 \%$ (Blomberg et al., 2009) Laboratory studies indicate that impairment in critical driving functions begins at low BACs and that most subjects are significantly impaired at 0.05\% BAC (Fell and Voas, 2006).

The alcohol consumption is particularly a crucial factor of accidents' risk in the group of young drivers. The relative risk of the accident with the fatal effect at the blood alcohol level of $0.5 \mathrm{mg} / \mathrm{ml}$ of driver with age of 16-19 is almost 60 times higher than at the sober driver with age of 30 (Keall, Frith and Patterson, 2004). Simultaneously the share of accidents after the alcohol consumption is particularly high in the group of young drivers. After passing the age border of 35 , the participation of accidents caused by drunk-drivers is considerably decreasing (Abdel-Aty and Abdelwahab, 2000).

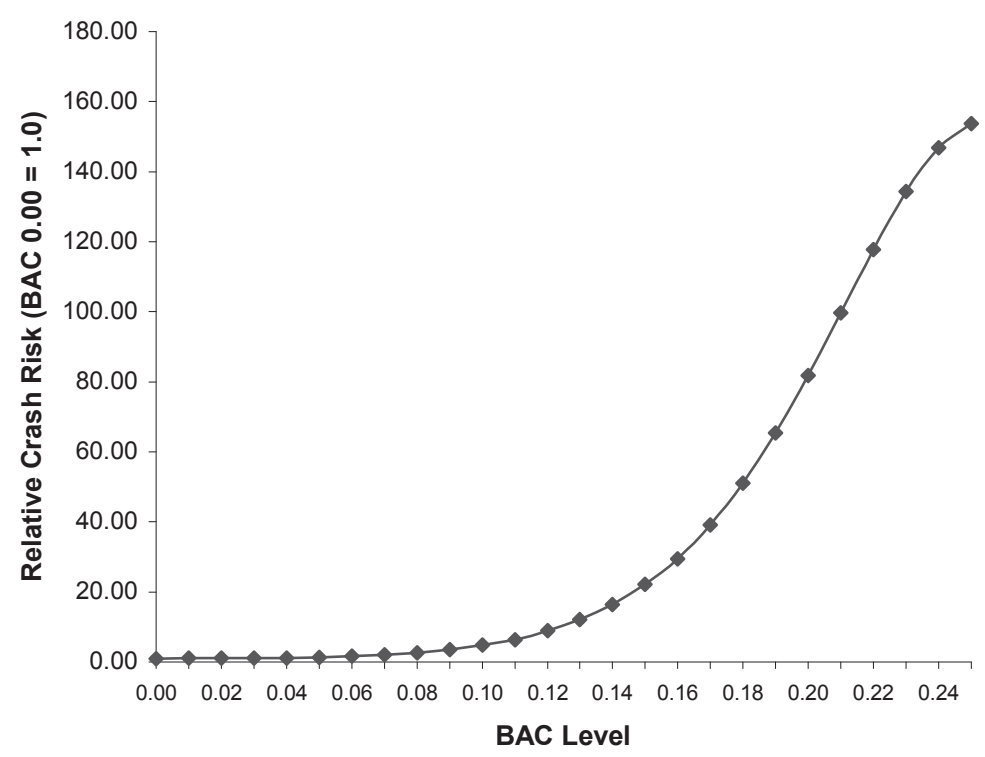

Figure 1. Alcohol influence to the risk of accidents

Source: Compton et al., 2002.

The relatively high participation of accidents in the group of young drivers results from their lower ability of avoiding accidents and higher approval of risky behaviors on the road. Young drivers who choose to drink and to drive 
after drinking probably have pre-existing characteristics that predisposed them to risk taking and crash involvement apart from any increased vulnerability to alcohol impairment (Peck et al., 2008)

Drugs and some medicines consumption is the factors increasing the risk of accidents. Particularly negative effects on the road safety has the combination of alcohol and drugs (Fell and Voas, 2009). Examinations results conducted in Netherlands and France show, that even little alcohol consumption (blood content of $0.5-0.8 \mathrm{mlg} / \mathrm{ml}$ ) at simultaneous drugs consumption increases the indicator of the relative risk of accidents of about $50 \%$ (Mathijssen and Houwing, 2005).

The hybrid era carries also other essential problem from the road safety point of view - ageing of the society. Elderly people are less vigilant and efficient than younger ones. It leads towards decresing the risk of road accidents. The main risk factors in the group of older drivers are: wrong evaluation of a situation on the road, wrong estimation of the distance to the preceding vehicle and the speed of other vehicles. That may lead to dangerous maneuvers. Also a risk of fainting or falling asleep while driving increases (Cicchino and McCartt, 2015).

Growing participation of deaths as a result of antisocial behaviors in the road traffic which end with accidents, are a distinctive feature of the hybrid era. The development of pathologies in the road traffic constitutes the more and more considerable social and economic problem. It is estimated, that on average for every country the annual share of social costs of road accidents fluctuates on the level from 1.5 to even $2.5 \%$ of its GDP. Globally, annual costs associated with road accidents' victims in the world amount about 520 billion USD.

\section{Road accidents in the European Union and their effects}

Transport is a crucial factor for fulfilling essential liberties of the European Union, i.e. free movement, the freedom to work or study and the free movement of goods and services. Therefore improvement of the transport services' quality, including personal safety and reducing the number of accidents and threats to health, is a priority of the transport policy (COM 144. 2009). Adopting this priority is a result of a great number of road accidents in Member States of the EU, generating high economic, personal and financial costs. They are mainly connected with the need of involvement of emergency services, police, fire fighters and others into providing assistance to the injured, expenses on the treatment, the rehabilitation and the psychological 
help, temporary or permanent inability of creating the GDP, costs of judicial proceedings or the payment of compensations and social benefits. (JaździkOsmólska, 2015).

Action taken by the European Commission and the individual EU member states in the scope of improvement in the road safety are bring measurable results. Number of killed in road accidents in UE-28 reduced from 57.1 thousand in 2000 to 31.5 thousand in 2010. (fig. 2), i.e. $44.8 \%$. In this period the total number of accidents decreased from 1461.7 thousand to 1130. 4 thousand, i.e. $22.6 \%$, and the number of injured in the accidents from 1983.5 thousand to 1502 . 2 thousand, i.e. $24.3 \%$ (Road safety evolution in $E U, 2016)$. Despite existing progress in the road safety improvement in Europe, the goal set by 2010 wasn't fully achieved. For the complete realization of stated objective that is cutting by half the number of fatalities, the number of road deaths in 2010 should be reduced almost by 3 thousand.

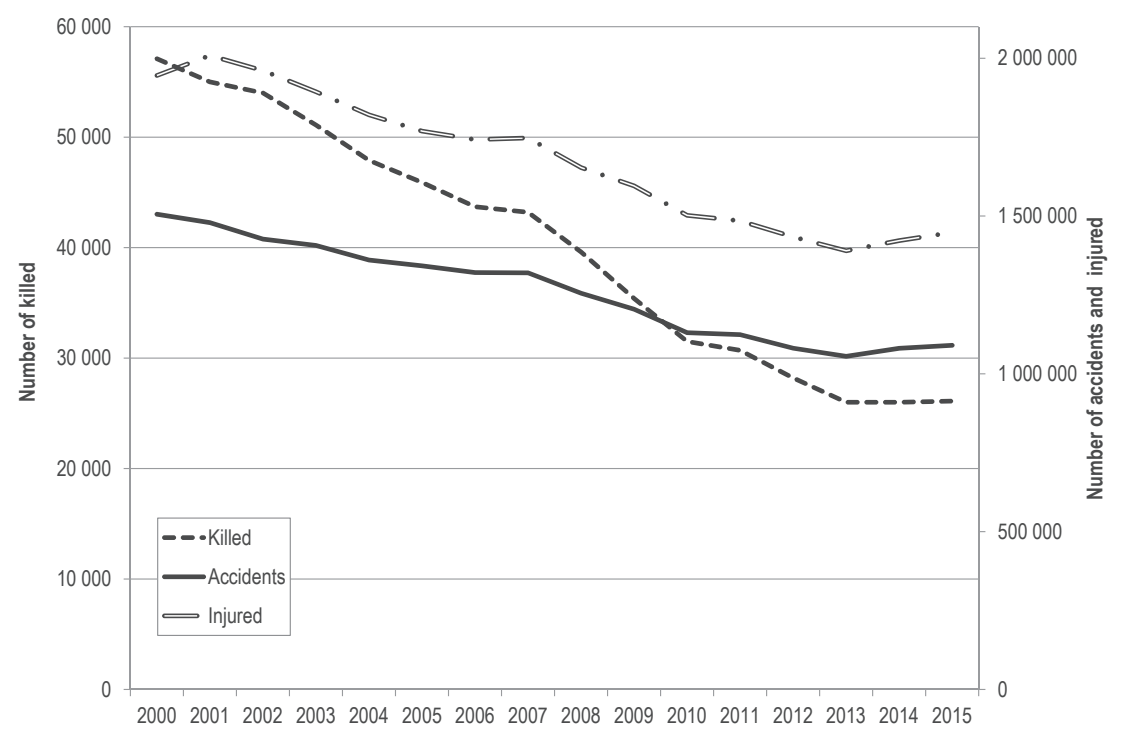

Figure 2. Number of accidents and i fatalities in UE-28

Source: own study on the basis (Road safety evolution in EU, 2016).

After 2010 dynamics of the road safety improvement has considerably reduced in the European Union. A considerable increase in the number of accidents and injured in 2014 and 2015 and fatalities in 2015 is a worrying phenomenon. In 2015 there were 1090.3 thousand accidents, i.e. by 35 
thousand more than in 2013 (increase of 3.3\%). In these accidents 1448.1 thousand people were injured, i.e. about 58.3 thousand more than in 2013 (increase of 4.2\%). The number of fatalities increased at that time of 100 people, i.e. $0.4 \%$. Such trends are an essential threat for achieving goals for the next decade, i.e. reducing the number of road deaths by $50 \%$. These trends were presented in figure 3 .

Young people are most often victims of accidents. In 2014 (the latest available data) almost 3.6 thousand people in age 18-24 were killed in road accidents in UE-28. It constituted $14 \%$ of the total number of killed in road accidents (fig 4). It should be noted that road accidents are the most frequent cause of death in this age group (fig. 5).

In the European Union there is a high spatial diversity of the risk of being involved in a fatal accident. Poland, in spite of the road safety improvement in recent years, is ranked among the group of countries with the high risk indicator, expressed by the number of fatalities per 1 million residents (fig. 6). The relative improvement in the safety in Poland is much higher than UE-28 average (fig. 7).

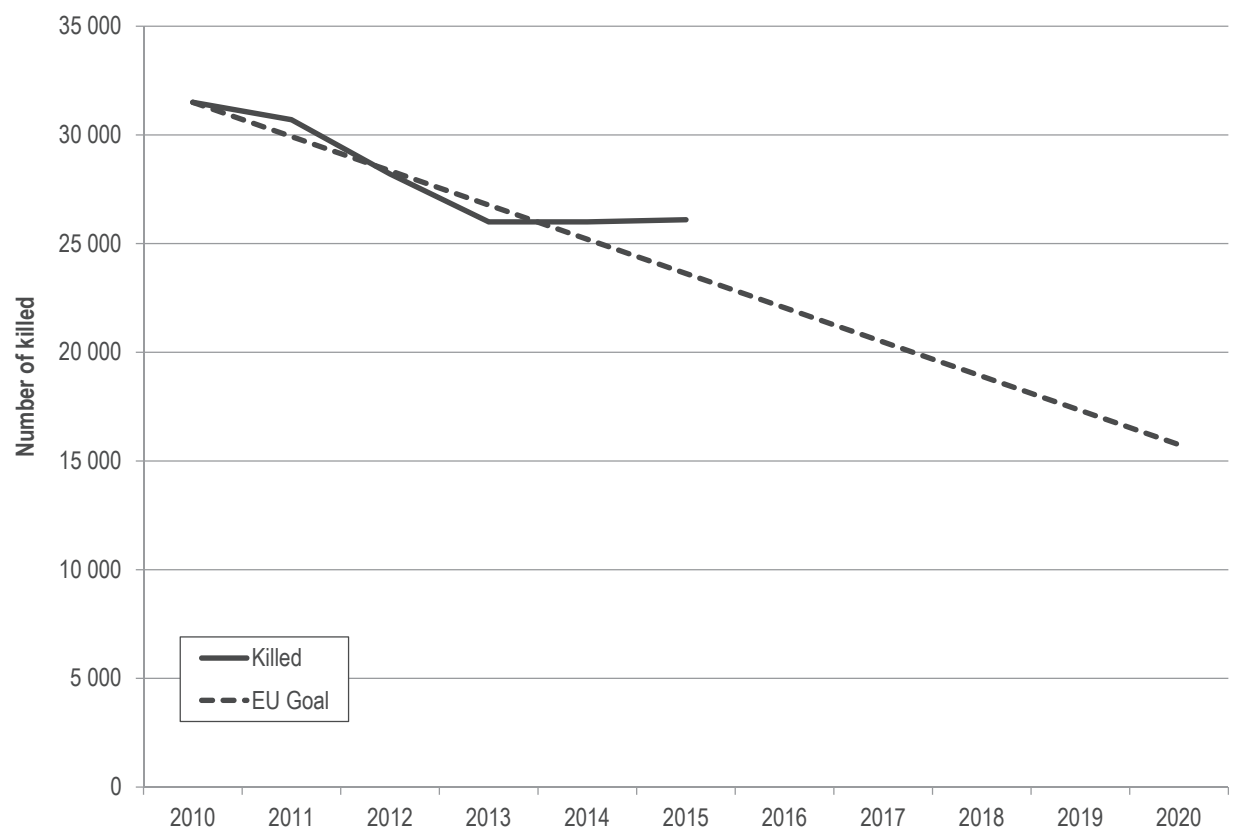

Figure 3. Goal accomplishment of reducing the number of fatalities in road accidents in UE-28 in the second decade of XXI century

Source: own study on the basis (Road safety evolution in EU, 2016). 


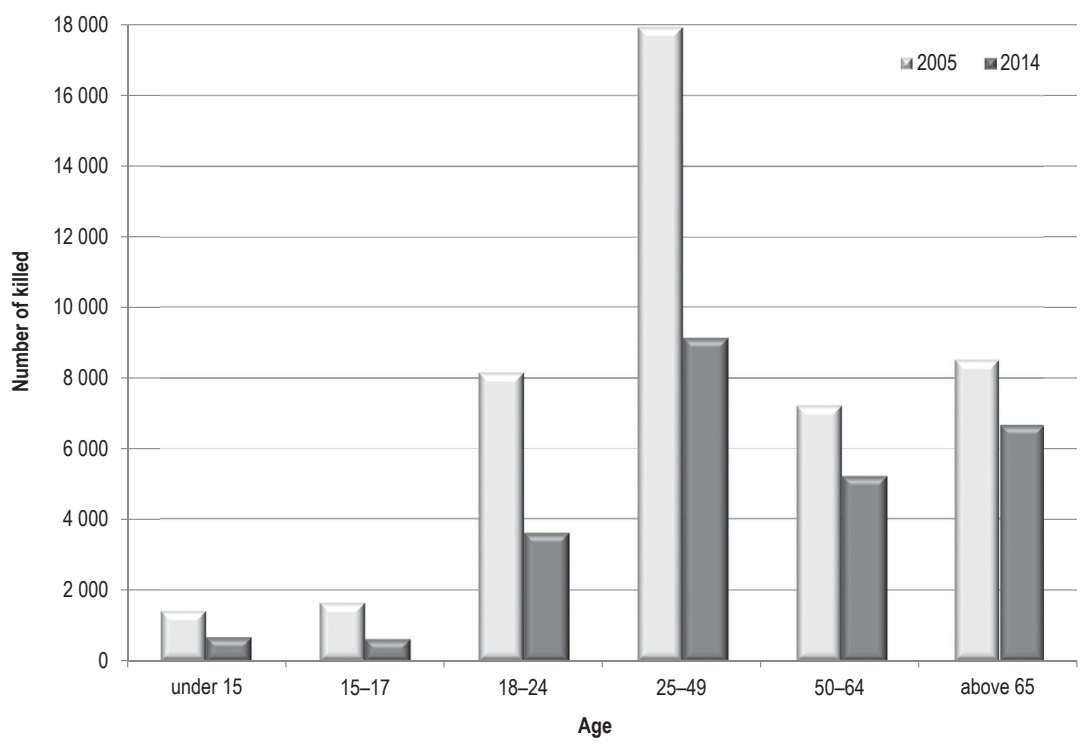

Figure 4. Number of fatalities in road accidents by age

Source: own study on the basis (Annual Accident Report 2016, 2016).

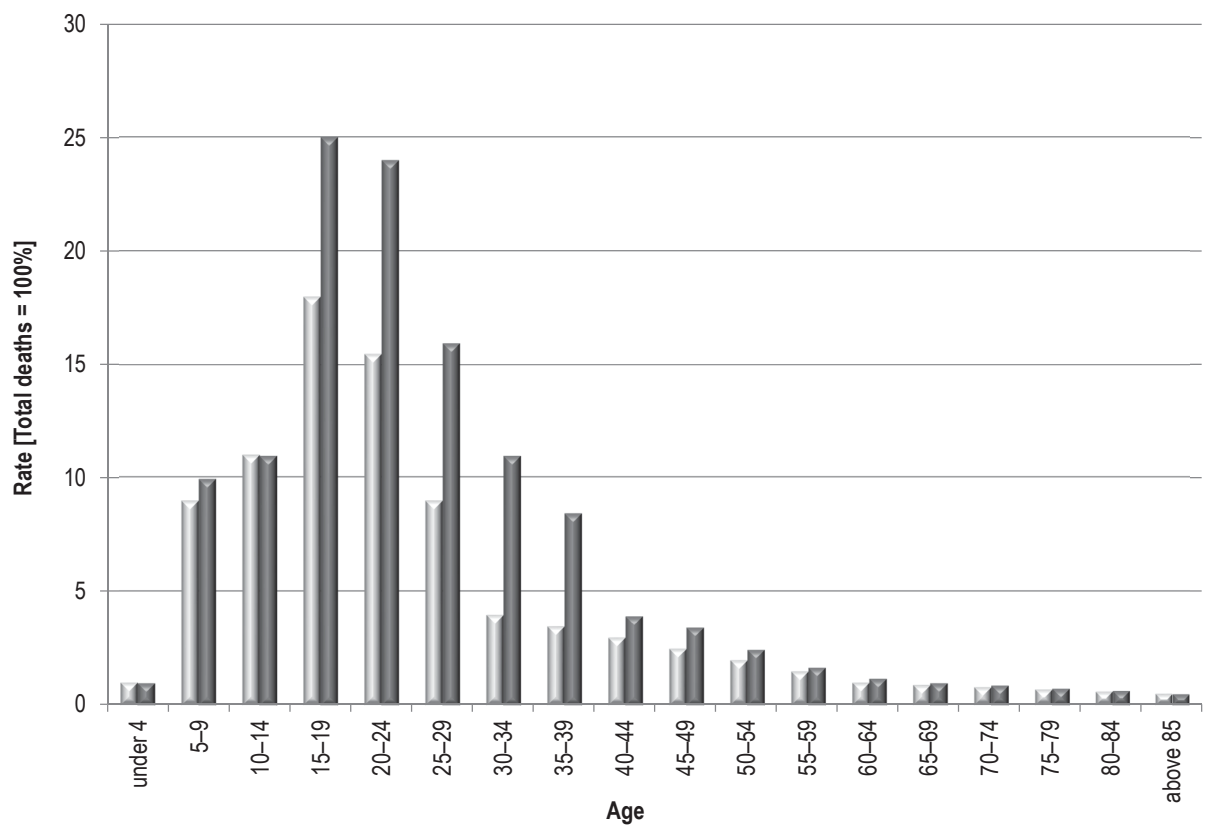

Figure 5. Participation of deaths caused by road accidents according to age groups Source: own study on the basis (Traffic Safety Basic Facts 2016, 2016). 


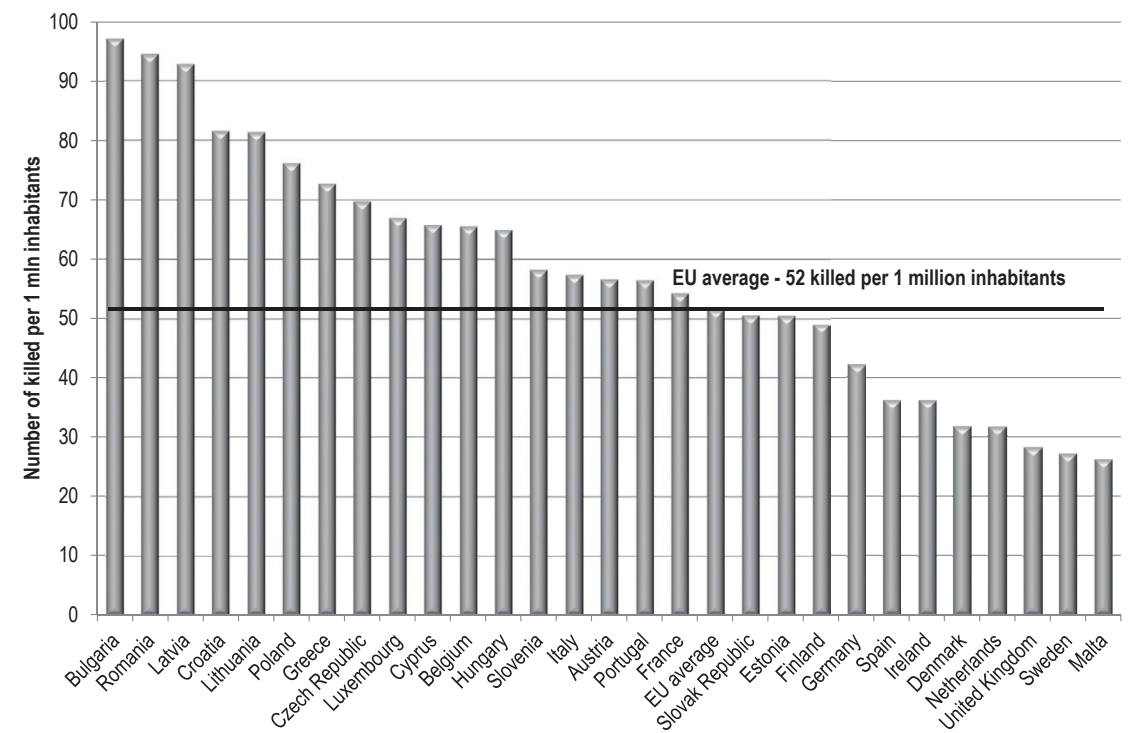

Figure 6. The road fatalities indicator per 1 million residents

Source: own study on the basis (Transport in Figures. Statistical Pocketbook 2016, 2016).

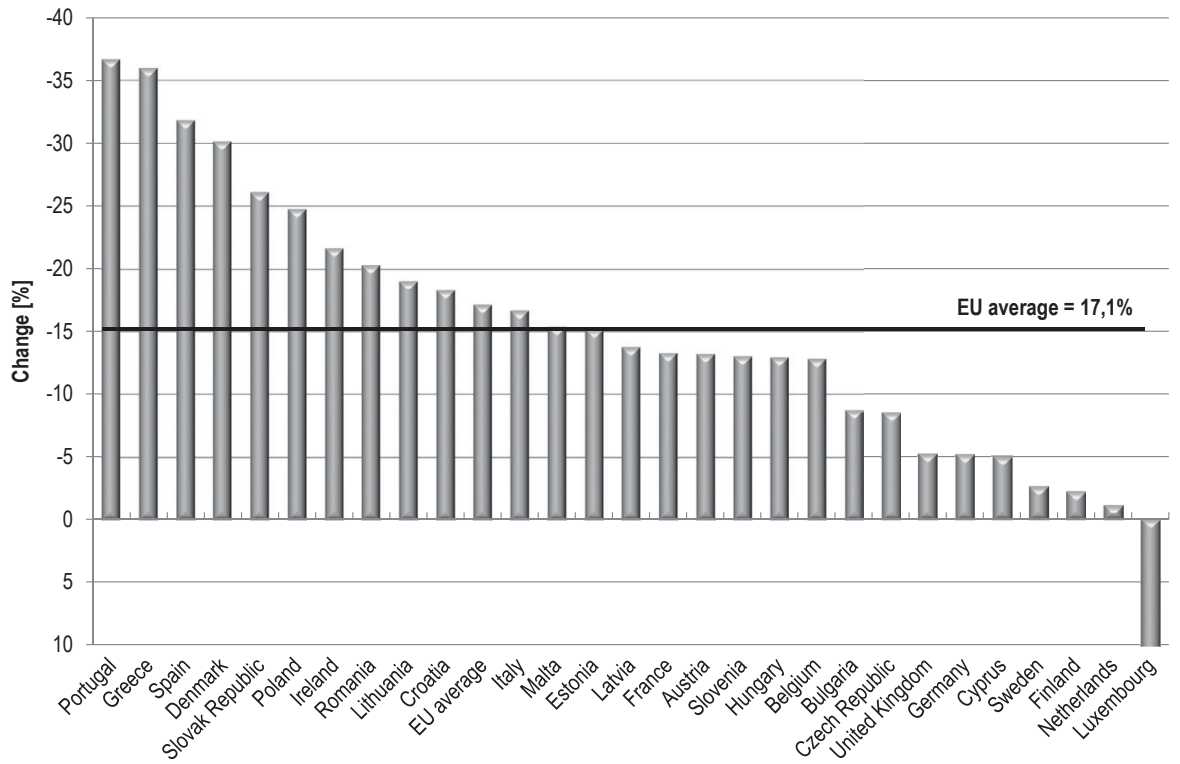

Figure 7. Change in the number of fatal road accidents in 2015 over the year 2010.

Source: own study on the basis (Transport in Figures. Statistical Pocketbook 2016, 2016). 
Countries located in the Centre and Eastern Europe are characterized by a much lower safty level than the European Union average. It results mainly from adjustment of the infrastructure to the current road traffic level The low density of dual carriageways and motorways causes, that the considerable part of the long-distance movement is held along single carriageways, where the accident's risk is much higher than on dual carriageways. On many roads there is a lack of city ring roads and non-collision crossroads. In consequence that may lead to increased prevalence of accidents. Also a technical condition of vehicles is a crucial factor. In countries of Centre and Eastern Europe people drive cars that were reversed from the movement in Western Europe. Many of them are post-accident vehicles, also not-equiped into devices and systems improving the ride safety, e.g. ABS (Anti-Lock Braking System), Bass (Brake Assist System), EBD (Electronic Brakeforce Distribution), ESP (Electronic Stability Program), on-track car position detection system in 'blind spot' of the mirror, Automatic Traction Control at starting, lane departure warning system, breathalyzer blocking the possibility of starting the car by the drunk driver etc.

In countries of Centre and Eastern Europe a low level of social capital is a crucial factor of higher level of road accidents. The low level of the knowledge on road safety and value system of many drivers that leads towards disregarding the risk, increases the number of road accidents.

Statistical data confirm that men are more often the accidents' victims. The most accidents happen in periods of of intense road traffic, mainly during holiday months (July, August). Almost a half of fatalities are drivers and passengers of passenger cars. Paradoxically, the most "favorable" conditions for road accidents are at good weather conditions (Raczyńska-Buława, 2016). Vehicles are then moving with higher speed, and drivers are more willing to take risky maneuvers.

Presented statistical data confirm the effectiveness of taken activity aimed at the improvement of the road safety. However the risk of accidents in the EU Member States is high.

\section{Road accidents in Poland and their effects}

In spite of appearing of the number of negative factors that may lead to increase the risks of accident, the safety level on Polish roads is improving. It is the effect of many actions taken through the state institutions, research institutions, non-governmental organizations, media, business entities and private people. However the safety level on Polish roads is still relatively low. 
In 2016 in more than 22.6 thousand accidents 3026 people were killed, and 40.8 thousand were injured. It was the first year in years, when there was an increase both in the number of accidents and their victims.

Table 1. Number of road accidents in Poland and their effects in 2000-2016

\begin{tabular}{|c|c|c|c|c|c|c|}
\hline \multirow{2}{*}{ Year } & \multicolumn{2}{|c|}{ Accidents } & \multicolumn{2}{c|}{ Killed } & \multicolumn{2}{c|}{ Injured } \\
\cline { 2 - 7 } & Total & $2006=100 \%$ & Total & $2006=100 \%$ & Total & $2006=100 \%$ \\
\hline 2000 & 57331 & 100.0 & 6294 & 100.0 & 71638 & 100.0 \\
\hline 2001 & 53799 & 93.8 & 5534 & 87.9 & 68194 & 95.2 \\
\hline 2002 & 53559 & 93.4 & 5827 & 92.6 & 67498 & 94.2 \\
\hline 2003 & 51078 & 89.1 & 5640 & 89.6 & 63900 & 89.2 \\
\hline 2004 & 51069 & 89.1 & 5712 & 90.8 & 64661 & 90.3 \\
\hline 2005 & 48100 & 83.9 & 5444 & 86.5 & 61191 & 85.4 \\
\hline 2006 & 46876 & 81.8 & 5243 & 83.3 & 59123 & 82.5 \\
\hline 2007 & 49536 & 86.4 & 5583 & 88.7 & 63224 & 88.3 \\
\hline 2008 & 49054 & 85.6 & 5437 & 86.4 & 62097 & 86.7 \\
\hline 2009 & 44196 & 77.1 & 4572 & 72.6 & 56046 & 78.2 \\
\hline 2010 & 38832 & 67.7 & 3907 & 62.1 & 48952 & 68.3 \\
\hline 2011 & 40065 & 69.9 & 4189 & 66.6 & 49501 & 69.1 \\
\hline 2012 & 37046 & 64.6 & 3571 & 56.7 & 45792 & 63.9 \\
\hline 2013 & 35847 & 62.5 & 3357 & 53.3 & 44059 & 61.5 \\
\hline 2014 & 34970 & 61.0 & 3202 & 50.9 & 42545 & 59.4 \\
\hline 2015 & 32967 & 57.5 & 2938 & 46.7 & 39778 & 55.5 \\
\hline 2016 & 33664 & 58.7 & 3026 & 48.1 & 40766 & 56.9 \\
\hline
\end{tabular}

Source: own study on the basis (Wypadki drogowe w Polsce w 2016 roku, 2017).

For achievement of EU aims in reduction the number of fatalities of road accidents, the number of people killed on roads in 2010 should not be higher than 3 147. This value was exceeded by 760 people, i.e. $24.2 \%$. In next years this aim also wasn't achieved (fig. 8).

The risk of the accident increases, as already stated, in case of drinkdriving or driving after drugs consumption. The number of accident with the participation of drink-drivers decreased from 4.5 thousand in 2010 up to the less than 3 thousand in 2016 (fig. 9), i.e. by 34\%. At that time the number of fatalities in road accidents was reduced by $15 \%$, and the injured by $39 \%$. Police activities have a significant influence on the indicators' fall. In 2010-2013 as a result of conducted inspections the Police eliminated c 140 thousand drink-drivers. In subsequent years this number, according to statistics of Police Headquarters, there was a considerable reduction - from 74 thousand in 2014 to 60 thousand in 2016 . However the detailed statisti- 
cal analysis show that the risk of the accident with the participation of the drunk-driver or drivers after drugs consumption is much higher than in case of sober road users (Płachecka, 2016).

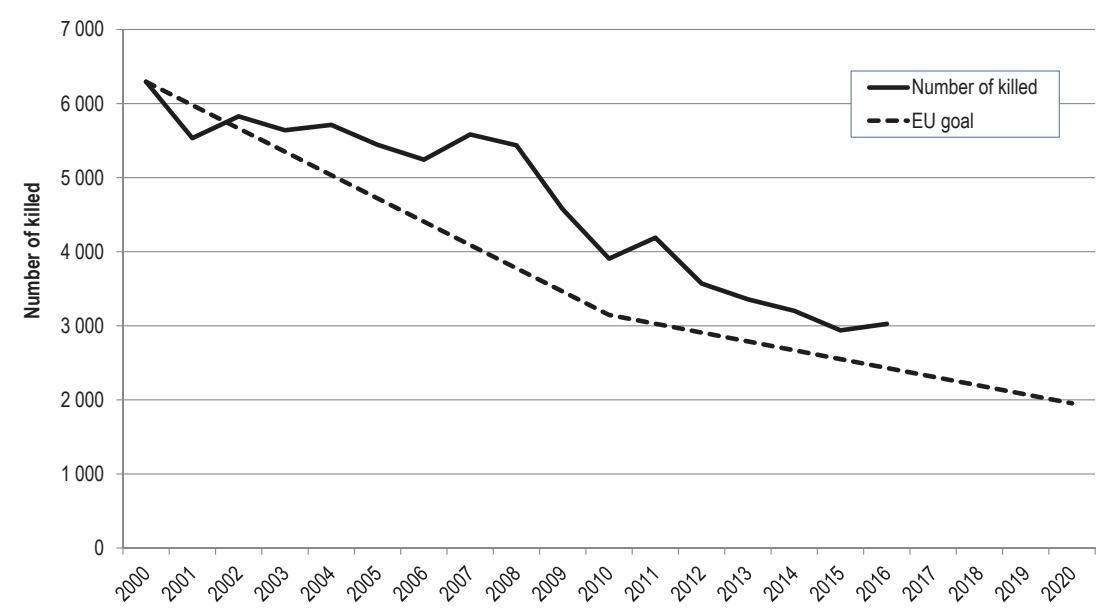

Figure 8. Changes in the number of fatal road accidents in Poland related to the EU aimy

Source: own study on the basis (Wypadki drogowe w Polsce w 2016 roku, 2017).

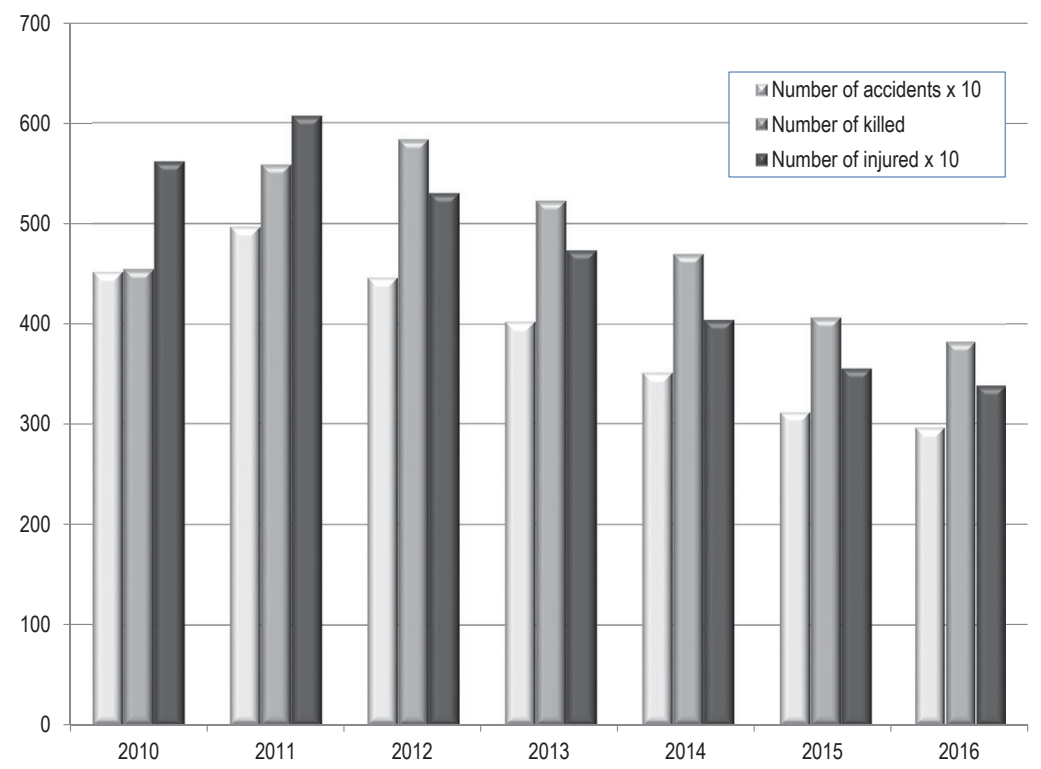

Figure 9. Accidents caused by drunk drivers

Source: own study on the basis (Wypadki drogowe w Polsce w 2016 roku, 2017). 
In 2016 in Poland there were 2973 accidents with children in age of 0-14. (tab. 2). In these accidents 72 children were killed and 3260 were injured. In relations to year 2010 the number of accidents with children decreased by $29.9 \%$, number of killed decrease by $35.7 \%$, and injured by $28.9 \%$.

Table 2. Road accidents with children in age of 0-14 in 2007-2016

\begin{tabular}{|c|c|c|c|c|c|c|}
\hline \multirow{2}{*}{ Year } & \multicolumn{2}{|c|}{ Accidents } & \multicolumn{2}{c|}{ Killed } & \multicolumn{2}{c|}{ Injured } \\
\cline { 2 - 7 } & Total & $\mathbf{2 0 0 7 = 1 0 0 \%}$ & Total & $\mathbf{2 0 0 7 = 1 0 0 \%}$ & Total & $\mathbf{2 0 0 7 = 1 0 0 \%}$ \\
\hline 2010 & 4239 & 100.0 & 112 & 100.0 & 4586 & 100.0 \\
\hline 2011 & 4077 & 96.2 & 102 & 91.1 & 4414 & 96.2 \\
\hline 2012 & 3679 & 86.8 & 89 & 79.5 & 3945 & 86.0 \\
\hline 2013 & 3454 & 81.5 & 90 & 80.4 & 3747 & 81.7 \\
\hline 2014 & 3210 & 75.7 & 80 & 71.4 & 3509 & 76.5 \\
\hline 2015 & 2820 & 66.5 & 70 & 62.5 & 3078 & 67.1 \\
\hline 2016 & 2973 & 70.1 & 72 & 64.3 & 3260 & 71.1 \\
\hline
\end{tabular}

Source: own study on the basis (Wypadki drogowe w Polsce w 2016 roku, 2017).

The vast majority of all victims amongst children in age up to 6 years are passengers (c 72\%). In older age groups passengers are c $45 \%$ of accidents' victims. Along with the age increase a participation of pedestrians and drivers accidents' victims increases. High share kids-passengers as accidents' victims shows that the youngest are exposed to the loss of life or health mainly because of adults' mistakes (Płachecka, 2016).

In spite of the significant improvement of the road safety, it isn't possible to recognize the existing situation satisfactory. A significant decrease in the number of killed or injured in road accidents contributed e.g.:

- modernization and development of the road infrastructure,

- development of the road traffic supervision system,

- improvement in the effectiveness of emergency and preventive services,

- management of the road safety system.

The road safety level depends mainly on the Police effectiveness. This includes issues like.:

- organising, supervising and execution of preventive tasks for the road safety,

- participation of the Police units in all-country and regional preventive programmes,

- increase in the number of police officers on duty directly on the road. 
A crucial factor of reducing the number of fatalities in road accidents have rescue actions towards the injured taken are by units operating as part of the National Fire and Rescue System and National Emergency Medical Services. As the number of these units is constantly rising a time of arrival to the accident is shortening. Also a number of cases, in which firefighters treat injured people in accidents is increasing (until, when the National Medical Rescue units will arrive at the place of incident) - it means that National Medical Rescue units are becoming ever better prepared for the help in this regard.

A crucial element for improving road safety has the National Road Safety Programme for years 2013-2020. This document defines purposes and directions of the state policy regarding the road safety. Their realization is supposed to be held as part of next realization programmes. The directions of action set in the National Road Safety Programme correspond with a current international recommendations (UN, the EU) in the road safety. However systematic implementation of instruments determined in this document is significant. Their lack can constitute a risk to achieve established purposes.

\section{Summary}

The economic and civilization development does not guarantee the prevention of death and disability. Statistical data presented in the article concerning road accidents and their effects confirm this thesis. Only in Poland, since the accession to the European Union, in spite of numerous activitis aimed at the improvement of the road safety almost 60 thousand people were killed, and almost 700 thousand injured in road accidents were hospitalized over a long period of time. Probably almost 50 thousand of them will never recover fully. That generates high economic and public costs.

The least recognized group of road accidents' effects is a group of people suffering emotionally. Psychological pain after the loss of close friends and family is the most difficult one in diagnosing and healing. It is also hard to determine precisely economic losses. Apart from expenses connected with the treatment and the rehabilitation, payment of compensations and benefits, losses resulting from the long-lasting or temporary impossibility of creating the GDP should be considered. Considering average values of the human life and financial losses recommended by experts of the Jaspers initiative (Jaspers, 2015) for infrastructure projects carried out in Poland, the value of economic costs of road accidents amounted above 21 trillion PLN in 2004-2016. 
The biggest problems in the fight against the threat of the health and life in the road traffic result from stereotypes still ruling in the Polish society, like e.g.: accidents are an inevitable and inherent element of the road traffic, and are caused by "ruts on roads", connecting the dynamic ride with the safe one is impossible, if somebody was killed it was only his own fault. Many people can't see also a problem in driving after drinking alcohol. The change of mentality is a necessary condition of the improvement in safety.

The factor which negatively affects unsatisfactory reduction in number of road accidents and their victims and its growth in 2016 increasing number of vehicles on Polish roads. The increasing availability of passenger cars, motorbikes causes, that their drivers have minor driving skills. Experts pay attention to the weakness of drivers' education system. Many people get the driving licence being able to park precisely the car on the training yard (going over the lines pointing outer edges of parking positions causes not-passing the examination), and at the same time not having an ability of moving on non-urban roads. Often during the course the candidate for driver never reaches the speed higher than $50 \mathrm{~km} / \mathrm{h}$, and after obtaining the driving license drives on roads where other vehicles move with much higher speed and must manoeuvre the way he has never trained. The factors affecting decrease in the dynamic of reducing the number of accidents in final years can be: legislative changes concerning confiscating a driving license or an elimination of the significant number of speed cameras.

The increase in the number of accidents in 2016 can also be a result of the risk's homeostasis occurrence (Wilde, 1988), having its source in behavioral theories. After a long period of the improvement in the safety an increase of risky behaviours on roads leading to the increase the number of road accidents can appear. This phenomenon can be confirmed in accident statistics. In all EU member states every few years there is an increase in road accidents, and then in a next period time there is a decrease.

\section{References}

Abdel-Aty, M. A. and Abdelwahab, H. T. (2000). Exploring the relationship between alcohol and the driver characteristics in motor vehicle accidents, Accident Analysis \& Prevention Vol. 32, No. 4, pp. 473-482. doi: 10.1016/S0001-4575(99)00062-7. Annual Accident Report 2016. (2016). Available at: https://ec.europa.eu/transport/road_safety/sites/roadsafety/files/pdf/statistics/dacota/asr2016.pdf (Accessed: 4 May 2017). 
Blomberg, R. D., Peck, R. C., Moskowitz, H., Burns, M. and Fiorentino, D. (2009). The Long Beach/Fort Lauderdale relative risk study, Journal of Safety Research, Vol. 40, No. 4, pp. 285-292. doi: 10.1016/j.jsr.2009.07.002.

Cicchino, J. B. and McCartt, A. T. (2015). Critical older driver errors in a national sample of serious U.S. crashes, Accident Analysis \& Prevention, Vol. 80. pp. 211 219. doi: 10.1016/j.aap.2015.04.015.

COM 144 (2009). White Paper. Roadmap to a Single European Transport Area - Towards a competitive and resource efficient transport system. European Commission.

COM 370 (2001). White Paper. European transport policy for 2010: time to decide. COM 389 (2010). Towards a European road safety area: policy orientations on road safety 2011-2020. Communication from the Commission to the European Parliament, the Council, the European Economic and Social Committee and the Committee of the Regions.

Compton, R. P., Blomberg, R. D., Moskowitz, H., Burns, M., Peck, R. C., Fiorentino, D., Peck, R. C., Risk, C. and Study, C. (2002). Crash Risk of Alcohol Impaired Driving, Proceedings of the sixteenth International Conference on Alcohol, Drugs and Traffic Safety ICADTS. Montreal.

Fell, J. C. and Voas, R. B. (2006). The effectiveness of reducing illegal blood alcohol concentration (BAC) limits for driving: Evidence for lowering the limit to .05 BAC, Journal of Safety Research Vol. 37, No. 3, pp. 233-243. doi: 10.1016/j. jsr.2005.07.006.

Fell, J. C. and Voas, R. B. (2009). Reducing illegal blood alcohol limits for driving: effects on traffic safety, [in:] Verster, J. C., Pandi-Perumal, S. R., Ramaekers, J. G., and de Gier, J. J. (eds) Drugs, Driving and Traffic Safety. Basel: Birkhäuser , pp. 415437. doi: 10.1007/978-3-7643-9923-8_26.

Jaspers (2015). Blue Book: Road infrastructure. Warsaw.

Jaździk-Osmólska, A. (2015). PANDORA - valuation method of social costs of road accidents in Poland, Roads and Bridges, Vol. 14, No. 2, pp. 133-142.

Keall, M., Frith, W. and Patterson, T. (2004). The influence of alcohol, age and number of passengers on the night-time rate of driver fatal injury in New Zealand, Crash Analysis \& Prevention Vol. 36, No. 1, pp. 49-61.

Krüger, H. P. and Vollrath, M. (2004). The alcohol-related accident risk in Germany: procedure, methods and results, Accident Analysis \& Prevention Vol. 36, No. 1, pp. 125-133. doi: 10.1016/S0001-4575(02)00134-3.

Mathijssen, R. and Houwing, S. (2005). The prevalence and relative risk of drink and drug driving in the Netherlands: a case-control study in the Tilburg police district. SWOV Institute for Road Safety Research. 
Murray, C. J. L. and Lopez, A. D. (eds). (1996). The global burden of disease: a comprehensive assessment of mortality and disability from deceases, injuries and risk factors in 1990 and projected to 2010. Harvard University Press.

Omran, A. R. (1971). The Epidemiologic Transition: A Theory of the Epidemiology of Population Change. The Milbank Memorial Fund Quarterly. Vol. 49, No. 4, pp. 509-538.

Peck, R. C., Gebers, M. A., Voas, R. B. and Romano, E. (2008). The relationship between blood alcohol concentration (BAC), age, and crash risk, Journal of Safety Research Vol. 39, No. 3, pp. 311-319. doi: 10.1016/j.jsr.2008.02.030.

Płachecka, M. (2016). Efekty działań na rzecz poprawy bezpieczeństwa w transporcie publicznym w Polsce, Autobusy - Technika, Eksploatacja, Systemy Transportowe, $\mathrm{nr} 10$.

Raczyńska-Buława, E. (2016). Bezpieczeństwo w ruchu drogowym w Europie: założenia polityki UE i ocena podejmowanych działań z perspektywy danych statystycznych, Autobusy - Technika, Eksploatacja, Systemy Transportowe, nr 10.

Road safety evolution in EU. (2016). Available at: https://ec.europa.eu/transport/ road_safety/sites/roadsafety /files/pdf/observatory/historical_evol.pdf (Accessed: 4 May 2017).

Rogers, R. G. and Hackenberg, R. (1987). Extending epidemiologic transition theory: A new stage, Social Biology, Vol. 34, No. 3-4, pp. 234-243. doi: 10.1080/ 19485565.1987.9988678.

SafetyNet. (2009). Alcohol.

Traffic Safety Basic Facts 2016. (2016). Available at: https://ec.europa.eu/transport/road_safety/sites/roadsafety/files/pdf/statistics/dacota/bfs2016_main_ figures.pdf (Accessed: 4 May 2017).

Transport in Figures. Statistical Pocketbook 2016 (2016).

Wilde, G. J. S. (1988). Risk homeostasis theory and traffic accidents: propositions, deductions and discussion of dissension in recent reactions, Ergonomics, 31. pp. 441-468.

World Health Organization (2015). Global Status Report on Road Safety 2015, WHO Library Cataloguing-in-Publication Data Global, p. 340. doi: 10.1136/ injuryprev-2013-040775.

Wróblewska, W. (2009). Teoria przejścia epidemiologicznego oraz fakty na przełomie wieków w Polsce, Studia demograficzne, 155(1), pp. 110-157.

Wypadki drogowe w Polsce w2016 roku. (2017). Komenda Główna Policji, Warszawa. 